Article

\title{
Turnover Intention among Field Epidemiologists in South Korea
}

\author{
Sukhyun Ryu $\mathbb{D}$ \\ Department of Preventive Medicine, College of Medicine, Konyang University, Daejeon 35365, Korea; \\ gentryu@onehealth.or.kr
}

Received: 31 December 2019; Accepted: 2 February 2020; Published: 4 February 2020

\begin{abstract}
The purpose of this study was to explore the level of occupational stress, job satisfaction, and turnover intention among Korean field epidemiologists, and to identify the factors that contribute to their turnover intention. We surveyed the Korean field epidemiologists in the cohort from 2016 to 2018 using the Occupational Stress Inventory, revised edition, and questionnaires developed from the Public Health Workforce Interest and Needs Survey. Fisher's exact test was used to identify the association between sociodemographic characteristics, occupational stress, job satisfaction, and turnover intention. Overall, 17 Korean field epidemiologists participated in this study (response rate: 74\%). More than half of field epidemiologists had turnover intention (53\%), and it was less likely to be present in the field epidemiologists recruited from the civilian sector than those recruited from the military (adjusted odds ratio, 0.59; 95\% confidence interval, 0.39-0.88). Furthermore, about two-thirds of field epidemiologists had a burden of occupational stress on Role Ambiguity (65\%), and only one respondent expressed satisfaction with the job. There was no significant relation among the levels of occupational stress, job satisfaction, and turnover intention. In this study, the field epidemiologists recruited from the military were more likely to have turnover intention. Additional studies to identify possible ways to reduce turnover intention among the public health workforce are warranted.
\end{abstract}

Keywords: occupational stress; satisfaction; turnover; job stress; workforce

\section{Introduction}

A field epidemiologist is a professional who applies the various epidemiologic tools to investigate the unexpected spread of infectious diseases in a time-constrained manner [1]. Many countries have initiated Field Epidemiology Training Programmes (FETPs) [2]. In 1999, the Korean FETP began to train the first group of military doctors for the position of field epidemiologist in the two-year full-time curriculum [3,4]. In October 2015, after the outbreak of Middle East Respiratory Syndrome in Korea, the FETP was opened to the public. Since 2016, field epidemiologists have been recruited among civilians as well as military doctors for the temporary two-year term position.

The primary duties of the field epidemiologist in Korea include investigation of outbreaks, design and operation of the surveillance program in the community, and the conducting of field research to identify risk factors of communicable diseases [5-10]. In the case of a communicable disease outbreak, field investigation often begins without a clear hypothesis and requires immediate response to identify the effective measure to control the complicated situation, which requires good communication skills [11]. The role of Korean field epidemiologists in the provincial or metropolitan government, whose affiliations are separated from the Korean Centers for Disease Control and Prevention (KCDC), can be very demanding because they often endure mandatory 24/7 on-call duties, professional isolation from the managerial staff of the department, and limited supervision and management support.

The average turnover rate of Korean field epidemiologists was $40 \%$ ( $45 \%$ for civilian, $37 \%$ for military) in the 2016-2017 cohort. The high turnover rate causes a considerable managerial cost, 
including replacement, recruitment, selection, and training of newly employed staff, and loss of organizational knowledge [12-14]. Despite the problem of exposure of the field epidemiologists to the very demanding environment and high turnover rate, there is no turnover-related literature available that specifically targets this group of professionals. The current study provides, for the first time, the status of turnover intention and the associative analysis of occupational stress, job satisfaction, and turnover intention among the field epidemiologists in Korea.

\section{Materials and Methods}

This was a cross-sectional study using the data obtained through a survey of Korean field epidemiologists employed from the provincial or metropolitan government from the years 2016 to 2018. The questionnaires were distributed to all currently active field epidemiologists on October 1, 2018. An anonymous self-administered questionnaire was used to assess the level of occupational stress, job satisfaction, and turnover intention. This study was approved by the ethics committee of the Institutional Review Board designated by the Korean Ministry of Health and Welfare (P01-201809-22-006). Written informed consent was obtained from all study participants.

\subsection{Demographics}

The demographic variables that were collected included age, sex, type of recruitment (physician from military or civilian sectors), length of employment, level of education, marital status, behavior customs such as smoking and drinking, and level of job demand including the number of calls from the field per day and the number of field deployments per week.

\subsection{Occupational Stress}

Occupational stress was measured using the Occupational Stress Inventory, revised edition (OSI-R), which has been well validated in other studies $[15,16]$ and represents a measure of three domains of occupational adjustment (occupational stress, psychological strain, and coping resources). Occupational stress was assessed by the Occupational Roles Questionnaire (ORQ) scale, which is a subscale of the OSI-R [17]. The ORQ consists of questions arranged in the six sections including Role Overload, Role Insufficiency, Role Ambiguity, Role Boundary, Responsibility, and Physical Environment, with ten items per section. The higher the score of ORQ, the stronger the level of stress is (Table A1 in Appendix A). In this study, the internal consistency (Cronbach's alpha) for the occupational stress was 0.77 (Role Overload), 0.78 (Role Insufficiency), 0.78 (Role Ambiguity), 0.77 (Role Boundary), 0.78 (Responsibility), and 0.77 (Physical Environment). This indicated that the subscales had good internal consistency [18].

\subsection{Job Satisfaction and Turnover Intention}

Self-perceived job satisfaction was examined by a single item, "How do you feel about your job?" and assessed by a 5-point scale, between 1 (extremely dissatisfied) and 5 (extremely satisfied) [19]. The previous studies demonstrated good reliability and validity of a single item-measure of job satisfaction $[20,21]$.

The turnover intention was assessed by providing two optional statements "Planning to or leaving before the assignment period for another job" and "Not planning to leave before the assignment," which is a modified version of the questionnaire used in the U.S. public health workforce interest and needs survey 2017 [22].

\subsection{Statistical Analysis}

We used descriptive statistics to demonstrate the sociodemographic, turnover intention, level of occupational stress, and job satisfaction of the study population. Fisher's exact test was used to identify the association between proportions of sociodemographic characteristics, occupational stress, and job 
satisfaction with turnover intention. To further identify factors associated with turnover intention, logistic regression analysis was performed. In this study, the statistical power for the Fisher's exact test and logistic regression analysis was 7\%. All statistical analysis was performed using $\mathrm{R}$ version 3.2.4 (R Foundation for Statistical Computing, Vienna, Austria). All statistical tests were two-sided, and a $p$-value $<0.05$ was considered as statistically significant.

\section{Results}

Among 23 Korean field epidemiologists, 17 voluntarily enrolled in this study, corresponding to a response rate of $74 \%$. The average age of study participants was 36 years (range of min-max: 26-58 years). By the type of recruitment, ten (59\% of total participants) were recruited from the military and seven were from the civilian sector. By the duration of the employment, seven (41\%) were employed less than a year, six (35\%) were employed between one and two years, and four $(23.5 \%)$ had been employed for two years or more. By the education level, twelve (71\%) had a bachelor's degree, three $(18 \%)$ held a master's degree, and two (12\%) had a doctorate. Eight (47\%) were married, and 16 (94\%) were non-smoker. Twelve $(71 \%)$ had a social habit of drinking alcohol. By the number of calls, ten (59\%) had less than three calls per day, four (24\%) were called four to five times per day, and three (18\%) had more than six calls per day. By the number of field deployments for the investigation of a possible outbreak, five (29\%) were deployed once a week or less, twelve $(71 \%)$ had two to three deployments per week. The only parameter that showed a statistical significance of association with turnover intention was a type of recruitment $(p=0.02)$. More than half of the field epidemiologists $(53 \%)$ expressed an intention, with strong prevalence among the epidemiologists recruited from the military sector (odds ratio, $0.05 ; 95 \%$ confidence interval, 0.01-0.19) (Table 1). No significant associations were identified between turnover intention and other sociodemographic aspects or the level of job demand, including the number of calls per day and the number of field deployments per week.

Table 1. Demographics of the study population and association with turnover intention.

\begin{tabular}{|c|c|c|c|c|c|c|}
\hline \multirow{2}{*}{ Variables } & \multicolumn{2}{|c|}{ Turnover Intention } & \multirow{2}{*}{$\begin{array}{c}\text { Total }(n=17) \% \\
(n)\end{array}$} & \multirow{2}{*}{ Odds Ratio } & \multirow{2}{*}{$95 \% \mathrm{CI}^{+}$} & \multirow{2}{*}{$p$-Value } \\
\hline & No $(n=8)$ & Yes $(n=9)$ & & & & \\
\hline \multicolumn{7}{|l|}{ Age, year } \\
\hline $25-29$ & 0 & 3 & $3(17.6)$ & - & - & \\
\hline $30-39$ & 4 & 6 & $10(58.8)$ & - & - & \\
\hline More than 40 & 4 & 0 & $4(23.5)$ & - & - & 0.21 \\
\hline \multicolumn{7}{|l|}{ Sex } \\
\hline Male & 6 & 8 & $14(82.4)$ & 1 (Reference) & - & \\
\hline Female & 2 & 1 & $3(17.6)$ & 0.40 & $0.01-9.36$ & 0.58 \\
\hline \multicolumn{7}{|l|}{ Type of recruitment } \\
\hline Military & 2 & 8 & $10(58.8)$ & 1 (Reference) & - & \\
\hline Civilians & 6 & 1 & $7(41.2)$ & 0.05 & $0.01-0.79$ & 0.02 \\
\hline \multicolumn{7}{|l|}{ Years of employment } \\
\hline$<1$ & 2 & 5 & $7(41.2)$ & - & - & \\
\hline $1-2$ & 4 & 2 & $6(35.3)$ & - & - & \\
\hline 2 years or more & 2 & 2 & $4(23.5)$ & - & - & 0.41 \\
\hline \multicolumn{7}{|l|}{ Marital status } \\
\hline Non married & 3 & 6 & $9(52.9)$ & 1 (Reference) & - & \\
\hline Married & 5 & 3 & $8(47.1)$ & 0.32 & $0.03-3.11$ & 0.35 \\
\hline \multicolumn{7}{|l|}{ Education level } \\
\hline Bachelor & 5 & 7 & $12(70.6)$ & - & - & \\
\hline Master & 1 & 2 & $3(17.6)$ & - & - & \\
\hline $\mathrm{PhD}$ & 2 & 0 & $2(11.8)$ & - & - & 0.46 \\
\hline \multicolumn{7}{|l|}{ Smoking } \\
\hline No & 7 & 9 & $16(94.1)$ & 1 (Reference) & - & \\
\hline Yes & 1 & 0 & $1(5.9)$ & 0.00 & $0.00-34.67$ & 0.47 \\
\hline
\end{tabular}


Table 1. Cont.

\begin{tabular}{|c|c|c|c|c|c|c|}
\hline \multirow{2}{*}{ Variables } & \multicolumn{2}{|c|}{ Turnover Intention } & \multirow{2}{*}{$\begin{array}{c}\text { Total }(n=17) \% \\
(n)\end{array}$} & \multirow{2}{*}{ Odds Ratio } & \multirow{2}{*}{$95 \% \mathrm{CI}^{+}$} & \multirow{2}{*}{$p$-Value } \\
\hline & No $(n=8)$ & Yes $(n=9)$ & & & & \\
\hline \multicolumn{7}{|l|}{ Drinking } \\
\hline No & 1 & 4 & $5(29.4)$ & 1 (Reference) & - & \\
\hline Yes & 7 & 5 & $12(70.6)$ & 0.20 & $0.01-2.84$ & 0.29 \\
\hline \multicolumn{7}{|l|}{ Number of calls } \\
\hline Less than 4 times per day & 4 & 6 & $10(58.8)$ & - & - & \\
\hline $4-5$ times per day & 2 & 2 & $4(23.5)$ & - & - & \\
\hline More than 5 times per day & 2 & 1 & $3(17.6)$ & - & - & 0.81 \\
\hline \multicolumn{7}{|l|}{ Number of field deployments } \\
\hline Once a week or less & 3 & 2 & $5(29.4)$ & 1 (Reference) & - & \\
\hline 2-3 times a week & 5 & 7 & $12(70.6)$ & 2.01 & $0.16-32.90$ & 0.62 \\
\hline
\end{tabular}

Based on OSI-R normative data, 47\% (Role Insufficiency), 29\% (Role Boundary), 18\% (Role Overload and Responsibility), and 12\% (Physical Environment) of respondents had been experiencing occupational stress. However, more than half (65\%) of the study population had a burden of occupational stress on Role Ambiguity (Figure 1).
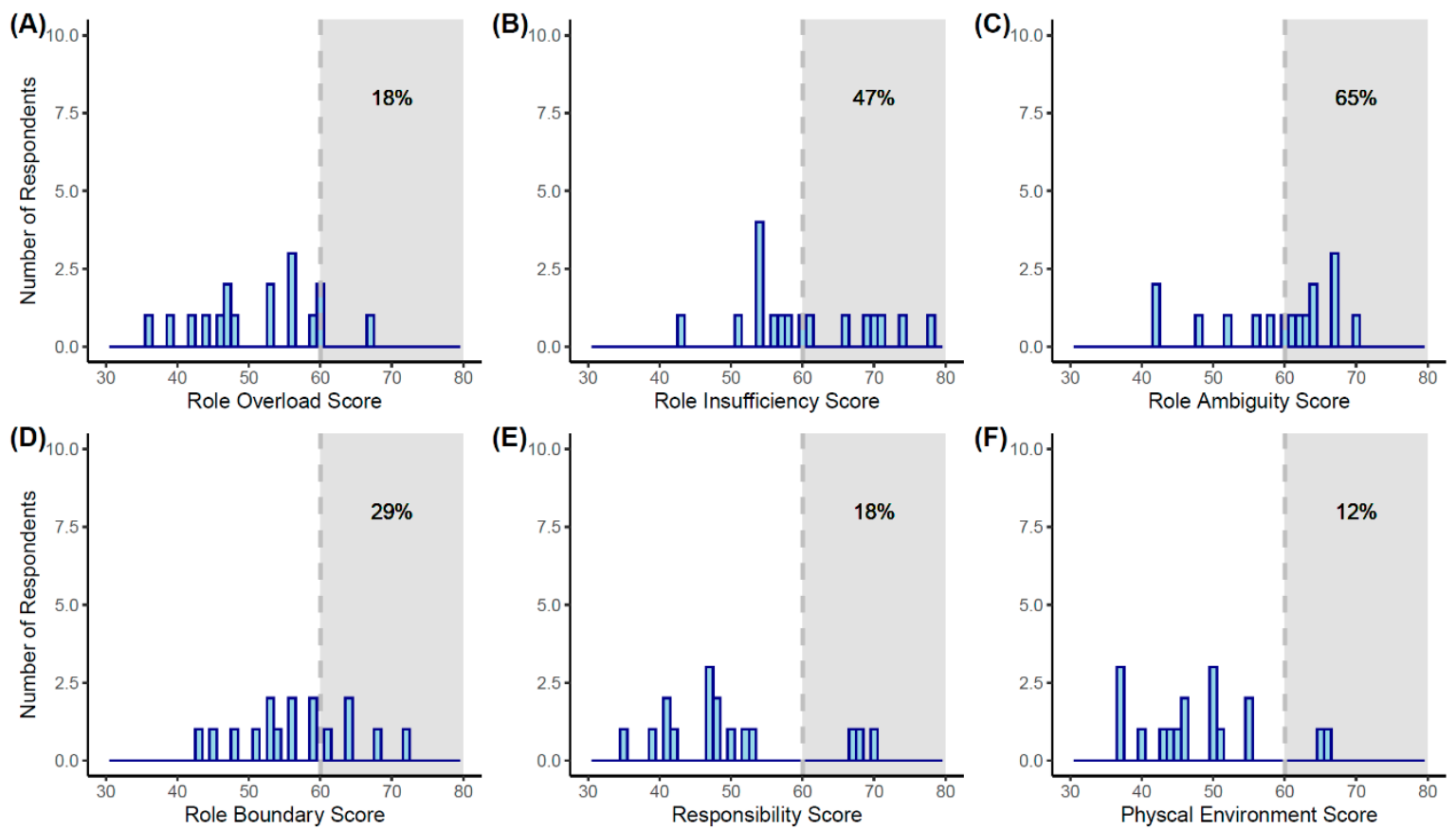

Figure 1. Occupational stress of each subdomain among the study population. Histograms depicting score frequency by the subdomains of (A) Role Overload, (B) Role Insufficiency, (C) Role Ambiguity, (D) Role Boundary, (E) Responsibility, and (F) Physical Environment. The shaded areas in which the T-score is larger than 60 indicate the presence of occupational stress in each subdomain.

Among the subdomain of occupational stress, Role Boundary was significantly associated with turnover intention $(p=0.049)$. However, no significant associations were identified between turnover intention and Role Overload, Role Insufficiency, Role Ambiguity, Responsibility, or Physical Environment (Table 2). Only one respondent expressed satisfaction with the job, in contrast to four respondents that reported dissatisfaction with their employment conditions. However, there was no significant association between job satisfaction and turnover intention (Table 2). 
Table 2. Association between occupational stress, job satisfaction, and turnover intention.

\begin{tabular}{|c|c|c|c|c|c|c|}
\hline \multirow{2}{*}{ Variables } & \multicolumn{2}{|c|}{ Turnover Intention } & \multirow{2}{*}{ Odds Ratio } & \multirow{2}{*}{$95 \% \mathrm{CI}^{+}$} & \multirow{2}{*}{$p$-Value } & \multirow{2}{*}{ Total $n(\%)$} \\
\hline & No $(n=8)$ & Yes $(n=9)$ & & & & \\
\hline \multicolumn{7}{|l|}{ Occupational stress } \\
\hline Role Overload & 3 & 0 & 0 & $0-2.21$ & 0.20 & $3(17.7)$ \\
\hline Role Insufficiency & 3 & 5 & 2.00 & $0.21-22.15$ & 0.64 & $8(47.1)$ \\
\hline Role Ambiguity & 6 & 5 & 0.44 & $0.03-4.73$ & 0.62 & $11(64.7)$ \\
\hline Role Boundary & 5 & 1 & 0.09 & $0.01-1.26$ & 0.049 & $6(35.3)$ \\
\hline Responsibility & 1 & 2 & 1.92 & $0.08-123.45$ & 1.00 & $3(17.7)$ \\
\hline Physical Environment & 2 & 0 & 0 & $0-4.60$ & 0.21 & $2(11.8)$ \\
\hline \multicolumn{7}{|l|}{ Job Satisfaction } \\
\hline Very Unsatisfied & 1 & 2 & - & - & & $3(17.7)$ \\
\hline Unsatisfied & 1 & 0 & - & - & & $1(5.9)$ \\
\hline Partly Satisfied & 6 & 6 & - & - & & $12(70.6)$ \\
\hline Satisfied & 0 & 1 & - & - & & $1(5.9)$ \\
\hline Very satisfied & 0 & 0 & - & - & 1.00 & 0 \\
\hline
\end{tabular}

The result of ordinal logistic regression analysis to further examine the significantly associated factors is shown in Table 3. The type of recruitment was the only factor that was significantly associated with turnover intention (adjusted odds ratio, $0.59 ; 95 \%$ confidence interval, $0.39-0.88$ ).

Table 3. Ordinal logistic regression of variables associated with turnover intention.

\begin{tabular}{cccccc}
\hline Variables & $\begin{array}{c}\text { Estimated } \\
\text { Coefficient }\end{array}$ & Standard Error & $\begin{array}{c}\text { Adjusted } \\
\text { Odds Ratio }\end{array}$ & $\mathbf{9 5 \% \mathbf { C I } ^ { + }}$ & $\boldsymbol{p}$-Value \\
\hline Intercept & 2.38 & 0.28 & - & - & $<0.01$ \\
\hline Type of recruitment & -0.53 & 0.20 & 0.59 & $0.39-0.88$ & 0.02 \\
\hline $\begin{array}{c}\text { Occupational stress (Role } \\
\text { boundary) }\end{array}$ & -0.35 & 0.21 & 0.70 & $0.47-1.06$ & 0.11 \\
\hline
\end{tabular}

${ }^{\dagger} \mathrm{CI}$ : confidence interval.

\section{Discussion}

In the light of growing demand for providing a quick and competent response to communicable diseases, the evaluation of the turnover intention and identification of relevant associated factors are crucial for retention and continuing operation of the professional workforce [14]. However, the long-term sustainability of training and operation of field epidemiologists is one of the biggest challenges across many countries [23,24]. In an attempt to address this problem, the current study was designed with the aim of identifying the possible contributory factors to the turnover intention in health professionals along with the previously known related factors, such as sex, age, length of employment, level of job demand, occupational stress, and job satisfaction $[14,25,26]$.

A recent study reported the burden of occupational stress on Role Overload and Physical Environment among field epidemiologists in Southeast Asia and Western Pacific Regions was 56\% and 53\%, respectively [16]. In the current study, there was less burden of occupational stress on Role Overload and Physical Environment. However, more than half of field epidemiologists that participated in the current study had the burden of occupational stress in Role Boundary; it is likely because the Korean field epidemiologists often have two authority lines from KCDC and the affiliated provincial or metropolitan government. Furthermore, more than half of the study participants had expressed the intention for turnover, an alarming fact by itself. Although the study was unable to determine the significant association between occupational stress, job satisfaction, and type of recruitment, a significant association between turnover intention and type of recruitment was identified. 
A possible explanation of high turnover intention among field epidemiologists from the military sector is that Korean men with a medical degree who usually trained as physicians mandatorily serve in military or government institutions for three years. These individuals are more likely to have the intention to leave the epidemiologist job to pursue clinical practice, and this may strongly affect the turnover intention of field epidemiologists from the military more than from the civilian sector.

Previous studies demonstrated that level of job demand, occupational stress, and low job satisfaction was associated with high turnover intention [26-29]. However, in this study, these were not associated significantly with the turnover intention. The unmeasured factors in the study, such as lower level of working hours and appropriate level of the income compared with other health professionals in Korea, may affect the result.

The Training Programs in Epidemiology and Public Health Intervention Network recommends the country's training program of the field epidemiologist as well as the human resources be supported and integrated with the Ministry of Health [30]. However, in South Korea, provincial and metropolitan governments directly recruit field epidemiologists, and some local governments have difficulty in recruiting among civilian sectors. Therefore, recruitment from the military sector is still a viable option. A previous study demonstrated that university-affiliated field epidemiologists are associated with reducing certain subdomains of occupational stress [16]; therefore, to recruit from the university-affiliated, not from military-affiliated personnel, may be one of the possible options to run the Korean program of field epidemiologists. However, more studies are required to identify possible ways to reduce turnover intention among Korean field epidemiologists.

The strength of this study is that this is the first study conducted in Korea that assessed the association between occupational stress, job satisfaction, and turnover intention among the public health workforce and explored the level of job demand, occupational stress, and job satisfaction as well as turnover intention. Therefore, this study provides useful information on the developing managerial strategy for countries that have various types of recruitment for the public health workforce including field epidemiologists.

Nevertheless, the current study has limitations. First, this study has low statistical power due to the small number of the study population. Second, a possible response bias due to the reliance on self-reporting may have influenced the results. Third, study results may have been affected by personal characteristics and personal traits that were not taken into consideration. Although these biases likely influenced the study results, the findings in this study are of importance for the guidance of implementation of larger scale studies in other public health sectors and the globe.

\section{Conclusions}

In the current study, field epidemiologists recruited from the military may be more prone to having turnover intention than those recruited from the civilian sector. Additional studies to develop the optimal strategies for the recruitment of the public health workforce are warranted.

Funding: This research received no external funding.

Acknowledgments: The author reports a past research grant from Mogam Science Scholarship Foundation. The author appreciates Ara Cho for the data analysis, and the Korean field epidemiologists who completed and returned the questionnaires.

Conflicts of Interest: The author declares no conflict of interest. 


\section{Appendix A}

Table A1. Interpretation of the occupational role questionnaire [16,17].

\begin{tabular}{cr}
\hline Subdomain & Interpretation \\
\hline Role Overload & A high score demonstrates their workload increasing and not having appropriate support. \\
\hline Role Insufficiency & A high score suggests their skills are unsuitable for their work. \\
\hline Role Ambiguity & A high score indicates a vague feeling of what they are expected in their work. \\
\hline Role Boundary & A high score suggests conflicting sense arising from the demands of their supervisor. \\
\hline Responsibility & A high score indicates a high level of responsibility for their job. \\
\hline Physical Environment & A high score suggests it is highly likely to have a high level of noise or an \\
& unpleasant situation. \\
\hline
\end{tabular}

\section{References}

1. Gregg, M. Field Epidemiology, 2nd ed.; Oxford University Press: New York, NY, USA, 2002.

2. Training Programs in Epidemiology and Public Health Intervention Network. Training Progrmas. Available online: https://www.tephinet.org/training-programs (accessed on 17 January 2020).

3. Kwon, G.Y.; Moon, S.; Kwak, W.; Gwack, J.; Chu, C.; Youn, S.K. Epidemic intelligence service officers and field epidemiology training program in Korea. Osong Public Health Res. Perspect. 2013, 4, 215-221. [CrossRef]

4. Lee, M.S.; Kim, E.Y.; Lee, S.W. Experience of 16 years and its associated challenges in the Field Epidemiology Training Program in Korea. Epidemiol. Health 2017, 39, e2017058. [CrossRef] [PubMed]

5. Ryu, S.; Kim, B.I.; Chun, B.C. An outbreak of respiratory tract infection due to Respiratory Syncytial Virus-B in a postpartum center. J. Infect. Chemother. 2018, 24, 689-694. [CrossRef] [PubMed]

6. Ryu, S.; Kim, C.K.; Kim, K.; Woo, S.H.; Chun, B.C. Serosurveillance of avian influenza A/H5N6 virus infection in poultry farmers, Gyeonggi Province, Republic of Korea, 2016-2017. Int. J. Infect. Dis. 2018, 75, 49-51. [CrossRef] [PubMed]

7. Ryu, S.; Won, S.A.; Uh, J.; Song, J.Y. Hepatitis A Virus Infection from a Contaminated Tap of Ground Water Facility in a Neighborhood Park, Republic of Korea. Infect. Chemother. 2019, 51, 62-66. [CrossRef]

8. Ryu, S.; Yang, K.; Chun, B.C. Community-acquired Legionnaires' Disease in a Newly Constructed Apartment Building. J. Prev. Med. Public Health 2017, 50, 274-277. [CrossRef]

9. Ryu, S.; Kim, J.J.; Cowling, B.J.; Kim, C. Surveillance and public health response for travelers returning from MERS-CoV affected countries to Gyeonggi Province, Korea, 2016-2017. Travel Med. Infect. Dis. 2019, 31, 101350. [CrossRef]

10. Ryu, S.; Chow, A.; Chun, B.C. Surveillance for Zika virus infection in travelers returning to the Republic of Korea. Travel Med. Infect. Dis. 2019, 29, 72-73. [CrossRef]

11. MacDonald PDM. Methods in Field Epidemiology; Jones \& Bartlett Learning: Burlington, MA, USA, 2012.

12. Jones, C.B. The costs of nurse turnover: Part 1: An economic perspective. J. Nurs. Adm. 2004, 34, 562-570. [CrossRef]

13. O’Brien-Pallas, L.; Griffin, P.; Shamian, J.; Buchan, J.; Duffield, C.; Hughes, F.; Spence Laschinger, H.K.; North, N.; Stone, P.W. The impact of nurse turnover on patient, nurse, and system outcomes: A pilot study and focus for a multicenter international study. Policy Polit. Nurs. Pract. 2006, 7, 169-179. [CrossRef]

14. Gan, Y.; Gong, Y.; Chen, Y.; Cao, S.; Li, L.; Zhou, Y.; Herath, C.; Li, W.; Song, X.; Li, J.; et al. Turnover intention and related factors among general practitioners in Hubei, China: A cross-sectional study. BMC Fam. Pract. 2018, 19, 74. [CrossRef]

15. Lu, L.; Cooper, C.L.; Chen, Y.C.; Hsu, C.H.; Wu, H.L.; Shih, J.B.; Li, C.H. Chinese version of the OSI: A validation study. Work Stress 1997, 11,79-86. [CrossRef]

16. Ryu, S.; Kim, Y.W.; Kim, S.; Liao, Q.; Cowling, B.J.; Lee, C.S. Occupational Stress among Field Epidemiologists in Field Epidemiology Training Programs from the Public Health Sector. Int. J. Environ. Res. Public Health 2019, 16, 3427. [CrossRef]

17. Osipow, S.H. Occupational Stress Inventory—Revised (OSI-R); Psychological Assessment Resources Inc.: Lutz, FL, USA, 1998.

18. Tavakol, M.; Dennick, R. Making sense of Cronbach's alpha. Int. J. Med. Educ. 2011, 2, 53-55. [CrossRef] 
19. Opie, T.; Dollard, M.; Lenthall, S.; Wakerman, J.; Dunn, S.; Knight, S.; Macleod, M. Levels of occupational stress in the remote area nursing workforce. Aust. J. Rural Health 2010, 18, 235-241. [CrossRef]

20. Dolbier, C.L.; Webster, J.A.; McCalister, K.T.; Mallon, M.W.; Steinhardt, M.A. Reliability and validity of a single-item measure of job satisfaction. Am. J. Health Promot. 2005, 19, 194-198. [CrossRef]

21. Wanous, J.P.; Reichers, A.E.; Hudy, M.J. Overall job satisfaction: How good are single-item measures? J. Appl. Psychol. 1997, 82, 247-252. [CrossRef]

22. Leider, J.P.; Harper, E.; Shon, J.W.; Sellers, K.; Castrucci, B.C. Job Satisfaction and Expected Turnover Among Federal, State, and Local Public Health Practitioners. Am. J. Public Health 2016, 106, 1782-1788. [CrossRef]

23. US Department of Health and Human Services. Field Epidemiology Training Program Development Handbook; US Department of Health and Human Services: Atlanta, GA, USA, 2006.

24. Bandoh, D.A.; Kenu, E.; Ameme, D.K.; Sackey, S.O.; Wurapa, F.; Afari, E.A. Sustainability of a field epidemiology and laboratory training programme: The Ghanaian story. Pan Afr. Med. J. 2019, 33, 68. [CrossRef]

25. Ferede, A.; Kibret, G.D.; Million, Y.; Simeneh, M.M.; Belay, Y.A.; Hailemariam, D. Magnitude of Turnover Intention and Associated Factors among Health Professionals Working in Public Health Institutions of North Shoa Zone, Amhara Region, Ethiopia. Biomed. Res. Int. 2018, 2018, 3165379. [CrossRef]

26. Oh, S.; Kim, H. Turnover Intention and Its Related Factors of Employed Doctors in Korea. Int. J. Environ. Res. Public Health 2019, 16, 2509. [CrossRef]

27. Lin, Q.H.; Jiang, C.Q.; Lam, T.H. The relationship between occupational stress, burnout, and turnover intention among managerial staff from a Sino-Japanese joint venture in Guangzhou, China. J. Occup. Health. 2013, 55, 458-467. [CrossRef]

28. Layne, C.M. The Relationship of Occupational Stress, Psychological Strain, and Coping Resources to the Turnover Intentions of Rehabilitation Counselors; Virginia Polytechnic Institute and State University: Blacksburg, VA, USA, 2001.

29. Van Dick, R.; Christ, O.; Stellmacher, J.; Wagner, U.; Ahlswede, O.; Grubba, C.; Hauptmeier, M.; Höhfeld, C.; Moltzen, K.; Tissington, P.A. Should I Stay or Should I Go? Explaining Turnover Intentions with Organizational Identification and Job Satisfaction. Br. J. Manag. 2004, 15, 351-360. [CrossRef]

30. Training Programs in Epidemiology and Public Health Intervention Network. TEPHINET Accreditation of Field Epidemiology Training Programs. Available online: https://www.tephinet.org/accreditation (accessed on 17 January 2020).

(C) 2020 by the author. Licensee MDPI, Basel, Switzerland. This article is an open access article distributed under the terms and conditions of the Creative Commons Attribution (CC BY) license (http://creativecommons.org/licenses/by/4.0/). 